University of Nebraska - Lincoln

DigitalCommons@University of Nebraska - Lincoln

Sociology Department, Faculty Publications

Sociology, Department of

2021

Constructing Pornography Addiction's Harms in Science, News

Media, and Politics

Kelsy Burke

Alice MillerMacPhee

Follow this and additional works at: https://digitalcommons.unl.edu/sociologyfacpub

Part of the Family, Life Course, and Society Commons, and the Social Psychology and Interaction Commons

This Article is brought to you for free and open access by the Sociology, Department of at DigitalCommons@University of Nebraska - Lincoln. It has been accepted for inclusion in Sociology Department, Faculty Publications by an authorized administrator of DigitalCommons@University of Nebraska - Lincoln. 


\title{
Constructing Pornography Addiction's Harms in Science, News Media, and Politics
}

\author{
Kelsy Burke \& Alice MillerMacPhee \\ University of Nebraska-Lincoln \\ Correspondence - Kelsy Burke, Department of Sociology, University of Nebraska-Lincoln, \\ 742 Oldfather Hall, Lincoln, NE 68588-0324, USA; e-mail: kburke@unl.edu.
}

\begin{abstract}
In order to describe pornography's harms in the twenty-first century, an age of unprecedented access to Internet technology, some advocates-including activists, religious leaders, politicians, and scientists-use a medical/scientific framework to claim that pornography is biologically addictive. This article examines public discourse on "pornography addiction" to extend theories of sociology of science and sociology of sexualities about scientific knowledge and the biomedicalization of sex and sexuality. Using content analysis of over 600 documents, including scientific studies, newspaper articles, and state government resolutions, we show how references to pornography as addictive emerged in the twenty-first century and grew most substantially in the last decade. We find that scientific studies largely offer inconclusive results, yet media and political discourses use biomedical scientific language to describe how pornography directly harms the physical and mental health of individual consumers, presumed to be men, and indirectly harms broader society. These include harms to heterosexual marriages and relationships, lawful society, and normal sexual desires. Thus, we find that pornography addiction serves as an illustration of how political actors and journalists are interpreters and claims-makers
\end{abstract}

Published in Social Forces 99:3 (March 2021), pp 1334-1362.

doi:10.1093/sf/soaao35

Copyright (C) 2020 Kelsy Burke \& Alice MillerMacPhee. Published by Oxford University Press on behalf of the University of North Carolina at Chapel Hill. Used by permission.

Published 24 April 2020. 
of scientific knowledge about sexuality in the public sphere. Scientific language, rooted in neurobiology, allows claims-makers to construct pornography addiction as a seemingly objective public threat that legitimizes stereotypes about binary gender and normative (hetero)sexuality.

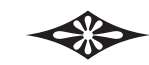

In the same way that a junkie eventually requires more and more of a drug to get a buzz or even feel normal, regular porn consumers will end up turning to porn more often or seeking out more extreme versions-or both-to feel excited again. And once the porn habit is established, quitting can even lead to withdrawal symptoms similar to drugs. ("How Porn Affects the Brain Like a Drug," Fight the New Drug website, 2017).

From our respective positions of rabbi-counselor and former Playboy model and actress, we have often warned about pornography's corrosive effects [... ]. This is a public hazard of unprecedented seriousness. ("Take the Pledge: No More Indulging in Porn," Wall Street Journal Op-Ed written by Schmuley Boteach and Pamela Anderson, 2016).

[P]otential detrimental effects on pornography's users can impact brain development and functioning, contribute to emotional and medical illnesses, shape deviant sexual arousal, and lead to difficultly in forming or maintaining intimate relationships, as well as problematic or harmful sexual behaviors and addiction. (Utah Concurrent Resolution on the Public Health Crisis, 2016).

Religious organizations and leaders, activists and advocacy groups, politicians, counseling and recovery programs, and mainstream media frequently reference addiction when describing widespread and frequent Internet pornography use (Stoops 2017; Oeming 2018; Perry 2019). For instance, 29 US states have proposed or passed resolutions declaring pornography addiction to be a "public health crisis." Though it is not currently classified in the Diagnostic and Statistical Manual (DSM), the preeminent diagnostic tool produced by the American 
Psychiatric Association, the concept emerged in the late twentieth century with roots in the sex addiction movement beginning in the 1970 s as well as media and scientific coverage of "cyber addictions" starting in the 1990s (Voros 2009). Advocates of a pornography addiction frame, unlike arguments against pornography that came before (see Strub 2010; Whittier 2018), claim medical and scientific authority to legitimize pornography's perceived harms (Clarkson and Kopaczewski 2013; Thomas 2013; Stoops 2017; Perry 2019).

This article examines what Ferree et al. (2002, 62) call "institutional and cultural access points" for actors to shape public debates and legislative activity over pornography addiction. Starting from the assumption that scientific claims are produced and influenced by a range of institutions and networks "beyond the laboratory door" (Frickel and Moore 2006, 8; see also Gauchat 2015), we examine the dissemination of such claims in peer-reviewed scientific journals, newspaper articles, and state resolutions declaring pornography a public health problem. Using qualitative and quantitative content analysis of over 600 sources, we show how these arenas of public discourse interact to construct the problem of pornography addiction. Social scientists and humanities scholars have analyzed and critiqued the science of sex addiction in general (Irvine 2005 [1990]; Reay, Attwood, and Gooder 2015) and pornography addiction specifically (Voros 2009; Attwood 2010; Paasonen 2011; Stoops 2017; Oeming 2018), but these works have both conceptual and empirical limitations. No study has systematically analyzed scientific studies of pornography addiction alongside other forms of public discourse. Our research thus disentangles scientific claims (i.e., those made by credentialed scientists in peer-reviewed scientific journals) from claims that sound scientific (i.e., those intentionally disseminated in media and political arenas).

Pornography addiction serves as an illustration of how political actors and journalists are interpreters and claims-makers of scientific knowledge. This article, therefore, contributes to sociology of science and sociology of sexualities literatures by extending theories of what pornography addiction as a framework discursively accomplishes in the social world. We find that discussions of pornography addiction perpetuate stereotypes about binary gender and (hetero) sexuality using scientific language to legitimize those stereotypes as objective and natural. We show how the cultural saliency of addiction 
as a biomedical phenomenon makes pornography addiction a seemingly neutral mechanism to maintain what Gayle Rubin (1984) calls the "charmed circle" of sexuality, or socially constructed boundaries between sexual desires and relationships that are good, natural, and healthy from those that are bad, unnatural, and unhealthy. Our findings thus support others who have critiqued the science of pornography addiction for admonishing queer forms of sexuality and endorsing heteronormativity (Voros 2009; Stoops 2017; Oeming 2018). We extend these critiques to argue that media and politics are the primary drivers of distorted scientific claims that exaggerate pornography addiction's harms.

\section{Knowledge Production, Science, and Sexuality}

Given that the contemporary United States is a "knowledge society" (Cetina 1999), individuals frequently use scientific claims to advance competing truths (Frickel and Moore 2006; Rose 2007; Evans 2018). Though the modern "age of experts" (Brint 1996) assumes that scientific authority stems from verified training and credentials, the cultural saliency of "free speech" in America means that individuals or groups outside of or on the fringe of established scientific institutions may assert and circulate scientific-sounding claims (Waidzunas 2015; Evans 2018; Scott 2019). The US anti-vaccination movement, for example, relies on scientific claims that have been widely discredited by medical authorities. Through qualitative interviews with parents who refuse to vaccinate their children according to pediatric guidelines, however, Reich (2018) finds that these parents integrate an understanding of "science" that aligns with their existing perspectives and disregard scientific knowledge that challenges it. In the words of Haraway (1999, 204), scientific discourses are "lumpy:" they "contain and enact" polysemic claims that can be used as a means to achieve various ends.

Claims-makers shape the dissemination of scientific knowledge to broader publics through the process of framing: intentional or unintentional curation of messages according to the motivations and values of those making claims (Epstein 1996; Benford and Snow 2000; Moore 2013; Stone 2019). In other words, science serves as a "discursive 
opportunity structure" (Ferree et al. 2002) for the media, government, social movements, and other public institutions to make claims about social problems and appropriate solutions (Frickel and Moore 2006; Evans 2018). An illustrative example is the "obesity epidemic," a modern US social problem constructed by scientific claims about the rise in the average American's body size and associated adverse health consequences. Yet as Saguy (2013) documents, the media acts as a filter for how most individuals receive scientific information and, in doing so, often uncritically reproduces research findings as definitive even if the scientific community understands that these findings have limitations.

When it comes to sex and sexuality, there is a robust body of literature demonstrating the use of scientific and medical discourse as regulatory forces in the modern Western world (Epstein 1996; Tiefer 1996; Laqueur 2003; Vogler 2019). Foucault (1990 [1978], 58) uses the phrase scientia sexualis to refer to a broad scientific understanding of sexuality that has come to dominate the "procedures for telling the truth of sex." Recent examples include scientific tests of sexual arousal that the media interprets as a tool to discover one's true and immutable sexual orientation (Waidzunas and Epstein 2015), sports organizations that use biologically based criteria for determining gender that implicitly reinforce heterosexuality and exclude and threaten intersex and transgender people (Westbrook and Schilt 2014; Davis 2015), and government officials who use social scientific studies to justify state control of reproduction (Balasubramanian 2018). Because science and medicine discursively produce meanings surrounding sexuality, these institutions also regulate and control sex and sexuality.

Recent interventions in studies of sexuality and science add clarity to Foucault's scientia sexualis on how sexed and sexual bodies are understood through medicalized and biomedicalized discourse. Medicalization, in this context, refers to the process by which sex and sexuality are framed as biologically oriented phenomena that therefore require medical "treatments" (Szasz 1991; Riska 2010). Biomedicalization is a late twentieth-century phenomenon marked by scientific understandings of health and disease that encompass broad notions of wellness and risk (Clarke et al. 2003; Rose 2007; Riska 2010). Erectile dysfunction is an example of medicalization: a modern diagnosis for male bodies who deviate from their "normal" sexual potential (to be 
erect) and can be treated with pharmaceuticals' techno-scientific advancements (e.g., Viagra), thus offering a medical route to restore normal masculine sexuality (Loe 2001; Potts et al. 2004). "Sexual health" is a modern phrase that offers an example of biomedicalization, reinforcing broad notions of the social good related to procreative, adult, and marital heterosexuality (Epstein and Mamo 2017). It is reflective of what Callahan $(2012,68)$ calls the "tyranny of health" where health describes universal values about well-being. The turn toward biomedicalization of sexuality marks a shift in focus, as described by Hallin, Brandt, and Briggs (2013), from the individual as "patient" to the individual as "citizen" (see also Hoppe 2018). As we describe in our findings, pornography addiction is an example of biomedical discourse that implicates groups and communities beyond the "universal body" (Potts et al. 2004) of medicalized discourse.

\section{Biomedicalization and Addiction}

In the United States, the concept of addiction has been thoroughly medicalized over the course of the twentieth century. In the 1960s and 1970 s, the increased social awareness that drug use was widespread among white, middleclass Americans, especially among veterans returning from the Vietnam War, prompted the US government to take interest in and support the small and marginal field of addiction science. Addiction science became mainstream as the state began supporting a therapeutic approach in addition to laws that criminalized drug use (Vrecko 2010a). Alongside a scientific industry that studies addiction using a medical or disease model, the medicalization of addiction has also fueled a profitable and expansive treatment industry (Travis 2010). The medicalized model of addiction removes blame from individuals for the cause of their addictions while maintaining pressure for individuals to successfully treat and overcome their addictions (Weinberg 2002). As such, medicalizing addiction has biomedical effects, reinforcing the neoliberal idea that self-control is desirable and healthy (Netherland 2012).

Another consequence of medicalizing addiction is that addiction as a medical condition can expand in scope to include an ever-larger number of cases (e.g., Reith 2004; Barker and Galardi 2015). Though 
early US sexologists, such as William Masters and Virginia Johnson, studied what they labeled "sexual disorders," they did not use an addiction framework (Irvine 2005 [1990]). Instead, the emphasis on sexual addictions, including addiction to pornography, stems from the addiction movements related to substance abuse (Reay, Attwood, and Gooder 2015). In the last half century, this movement has begun to identify and treat a wide range of addictions related to various behavioral pleasures, such as eating, gambling, and sex (Travis 2010; Netherland 2012). Founded in 1977 by a longtime Alcoholics Anonymous (AA) member, Sex and Love Addicts Anonymous (SLAA) was the first established sex addiction support group. In the 1990s, the addiction movement began targeting pornography addiction, which they connected to both sex and Internet addictions (Irvine 2005 [1990]; Voros 2009). Conservative Christian leaders and organizations, which have long opposed pornography on moral grounds, championed the addiction framework in late twentieth-century messages about pornography's harms (Thomas 2013; Perry 2019; Burke and Haltom 2020). Radical feminists, who have maintained their opposition to pornography since the 1970 s (Whittier 2018), remain in coalition with religious anti-pornography groups but have not taken up the language of addiction like their conservative Christian counterparts. Instead, evangelicals and feminists find common motivation on the basis of freedom from so-called sexual exploitation, language that, according to Bernstein (2018), reflects the rise of the neoliberal state and militarized humanitarian efforts.

Science legitimizes what counts as an addiction, and thus new scientific evidence must be marshaled to establish behavioral addictions. A proliferation in neuroscientific studies has sought to measure (or contest) biological predictors and effects of a wide range of potentially addictive behaviors, such as gambling, gaming, and using the Internet (Petry, Zajac, and Ginley 2018). Though sociologists of addiction do not reject the notion that genetic or neurological factors influence addictions (see Vrecko 2010b), this work does critically interrogate the context that produces and disseminates scientific claims about addiction (Netherland 2011, 2012). Addiction is widely understood in modern US society to be caused by biological factors (indeed, the National Institute on Drug Abuse describes addiction as a brain disease), but in practice, addictions are typically diagnosed using nonbiological 
criteria (such as social functioning) and treated with the goal of reducing social strain and restoring social order (Keane 2002; Weinberg 2002).

Sex addiction broadly, and pornography addiction specifically, is a contested concept within scientific communities (see Kor et al. 2013; Moser 2013; Petry, Zajac, and Ginley 2018). Our research does not strive to debunk scientific studies of pornography addiction or to take a stand in debates over whether pornography addiction is real. Instead, we examine how scientific studies debate pornography addiction discourse and how this is deployed in the public sphere of media and politics. Though behavioral addictions are broad in scope and have a range of lay and clinical support, they have not mobilized political activism and advocacy in the same way as pornography addiction. There are no movements that are comparable in size or scope related to gambling, sugar, or shopping addictions. Because we know that public debates over sex reflect broader social values and stigmas (Rubin 1984), we examine what "biological addiction" language can discursively accomplish when it comes to articulating the harms of pornography within the realms of science, media, and politics. We find that this seemingly objective scientific language is used by a range of social actors to perpetuate gender and sexual stereotypes.

\section{Data and Methods}

Drawing from qualitative and quantitative content analysis, we analyze discourse in three arenas in which "pornography addiction" emerges: scientific literature, newspaper articles, and state government resolutions. ${ }^{1}$ First, we used PubMed, a database of more than 27 million references hosted by the US National Library of Medicine, to search for scientific studies from medical and health-related fields. We found 127 peer-reviewed articles written in the English language that contained reference to pornography addiction ("pornography/porn addict," "pornography/porn addiction," "addicted to pornography/porn") anywhere in the text. Our final dataset for in-depth analysis includes 103 scientific articles published between 1992 and 2017. Most scientific articles ( $n=70$ or 68 percent) come from psycho-social studies or those from psychology or the social sciences that rely 
on methods of self-reporting via survey questionnaires (the most common method), interviews, and/or focus groups. Our sample includes 11 neuro-physiological studies (11 percent) that use some neurological or physiological measure, sometimes in combination with self-report through interviews or surveys, including functional magnetic resonance imaging (fMRI or MRI), eye tracking, skin conductance, and photoplethysmogram (PPG). The remaining 21 articles (20 percent) were review studies, which surveyed the state of the field in a particular area but did not include original research.

Our second data source is a sample of newspaper articles collected using LexisNexis, an online searchable database that includes more than 15,000 news, legal, and business sources. We first searched for any reference to "pornography addiction" or its equivalent anywhere in the text of US English language newspapers, resulting in 1,376 articles. For in-depth analysis, we limited our search to newspaper articles where "porn" or its variations (pornography, pornographic) appeared in the headline or byline. We then excluded articles that did not focus on pornography consumption, such as those focused on the pornography industry. Our final sample for in-depth analysis included 489 articles published between 2001 and 2017. We chose to include each publication from articles republished in multiple newspapers in order to capture the magnitude/impact of these articles. The newspaper sample includes articles from 29 states and Washington DC, including those with national prominence, such as The New York Times and the Los Angeles Times, as well as a range of state and local publications. Within our sample of articles, we coded the majority ( $n=$ 329,67 percent) as news articles, 95 articles (20 percent) were opinion-editorial pieces (op-eds), and 65 (13 percent) were advice columns.

Our third data source includes state-level government resolutions, describing pornography as addictive. We began with an Internet search for "pornography" and phrases related to the Utah resolution (the first of its kind to be signed into law), including "public health crisis" or "public health concern." Table 1 lists the 29 states that have proposed resolutions as of this writing. We identified 18 states that had a resolution in some stage of the legislative process before 2018 and use these resolutions for our analysis to maintain date consistency across our data sources. All resolutions use similar language that we traced to a model resolution drafted by the National Center 
for Sexual Exploitation (NCOSE) in 2016 that targets Utah. The remaining resolutions' texts differ slightly and none explicitly reference Utah or NCOSE. ${ }^{2}$

To analyze the data, members of the research team (both co-authors and research assistants) first coded each scientific study, newspaper article, and state resolution based on several explanatory criteria obtained by skimming or using the "find" function to search for relevant terms. For all data sources, we used a Google Spreadsheet to classify titles, authors, publication date, location, and if the consumer(s) of pornography described were explicitly young people (references to "children," "millennials," "teens/teenagers," "students"- including college/university-or "youth”), men only, women only, and men and women, or if there were no gender markers used. We also classified the "addiction conclusion" and whether an article supported or challenged an addiction framework. For newspaper articles, we also coded for "speakers:" any individual or organization referenced within an article (Ferree et al. 2002). We then examined patterns related to frequencies for these explanatory data.

For in-depth qualitative coding, at least two members of the research team analyzed each article using the qualitative data analysis software, NVivo, to ensure cross-coder reliability (Neuendorf 2002). Our goal was to examine discourse surrounding the causes and consequences of pornography addiction. We used an "in vivo" approach where we included the exact language used in the articles that described causes, consequences, or correlations (relationships that did not specify causation). We then created broad categories based on these codes, capturing common themes (Strauss 1987). The final stage of coding was to perform in-depth analysis based on these categories where we coded "line-byline" (Strauss 1987) to capture references to these categories and the context by analyzing newspapers' and state resolutions' entire text and scientific articles' abstracts (if an article's abstract was missing or did not contain enough information related to the categories of harm, we then read the Introduction and Discussion/Conclusion sections of the articles). For some categories that few articles referenced, we were able to analyze every article. For other categories (like harm to health), we randomly sampled articles to code until we reached a saturation point, or when coding additional articles revealed no new ideas or themes (this number differed for each category). 


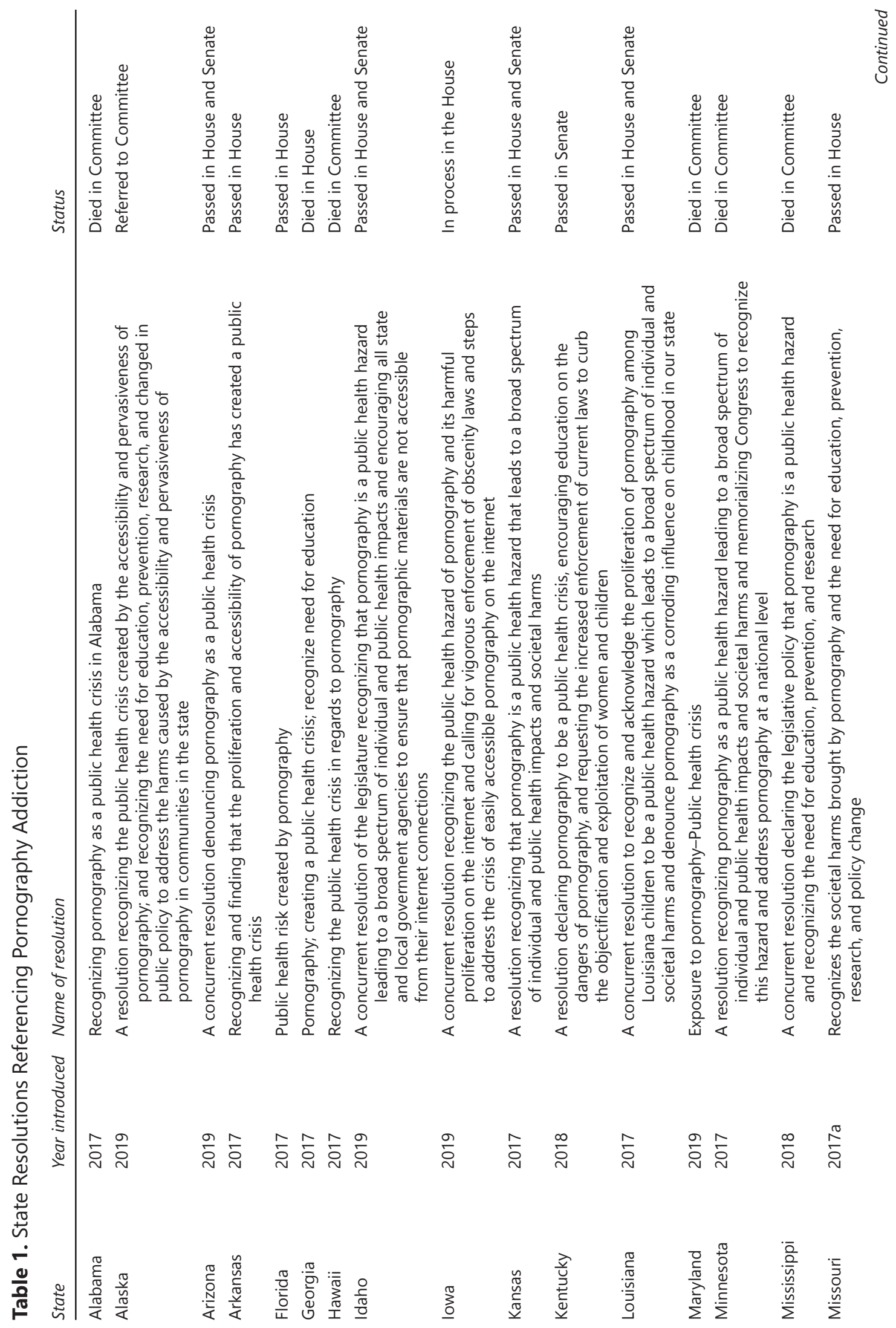




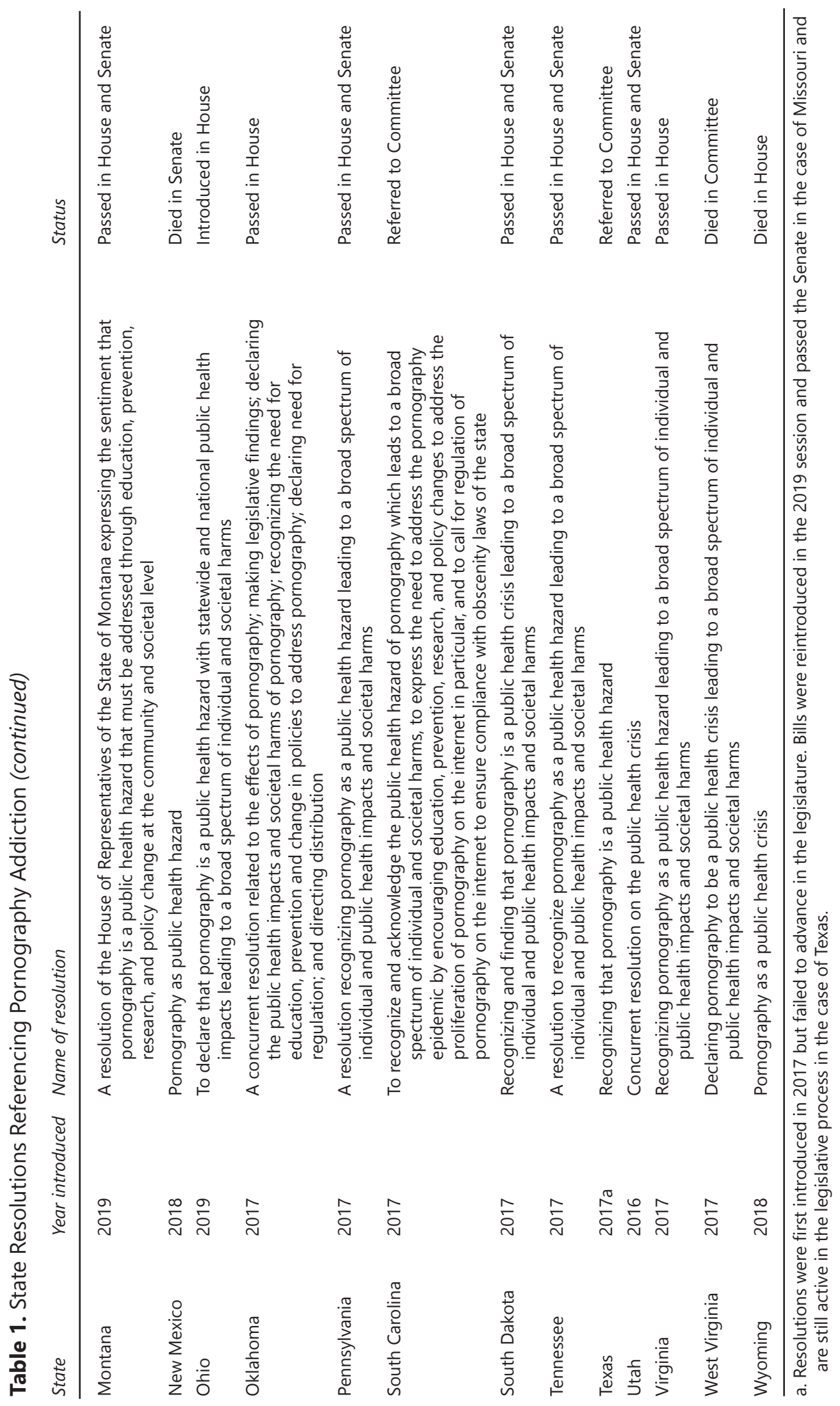


One limitation of our methods (and opportunity for future research) is that we do not examine context for our data. For instance, we do not include the number of times a scientific article has been cited or the impact factor of the journal article. We do not compare scientific studies that reference "pornography addiction" with those that study pornography consumption without referencing this framework. We do not consider varying readership of newspapers (e.g., Utah newspapers publish a large number of articles mentioning pornography addiction but have a limited readership compared to New York newspapers, which publish fewer articles on the topic).We do not discuss the political context of the states that consider pornography-related resolutions. Instead, the goal of our study is to examine these different data sources to understand how public discourses engage the concept "pornography addiction" to assess how this phrase conveys cultural meaning.

\section{Pornography Addiction Discourse in Science, Media, and Politics}

Figure 1 shows the number of scientific and news articles published each year until 2017, illustrating the rise of pornography addiction as a medicalized concern. Virtually absent before 2000, media and scientific attention to pornography addiction increased substantially in the past decade. Before 2010, 366 newspaper articles reference pornography addiction. Since then, there have been 1,010 published newspaper articles. For scientific articles, 27 articles were published before 2010, and 101 articles published since. State resolutions (see table 1) emerged in 2016 with one state's passage (Utah) and had a marked increase in a single year. In 2017, 17 states introduced these resolutions.

Most newspaper and scientific articles and state resolutions that mention "pornography addiction" implicitly or explicitly endorse it. As shown in figure 2, all state resolutions support an addiction framework for pornography along with the majority of newspaper articles (91 percent) and scientific articles (72 percent).We coded "support" for pornography addiction among those texts that use the phrase "pornography addiction" uncritically, taking for granted that pornography can be addictive. We coded "challenge" to pornography addiction among those texts that questioned evidence of pornography's addictive 


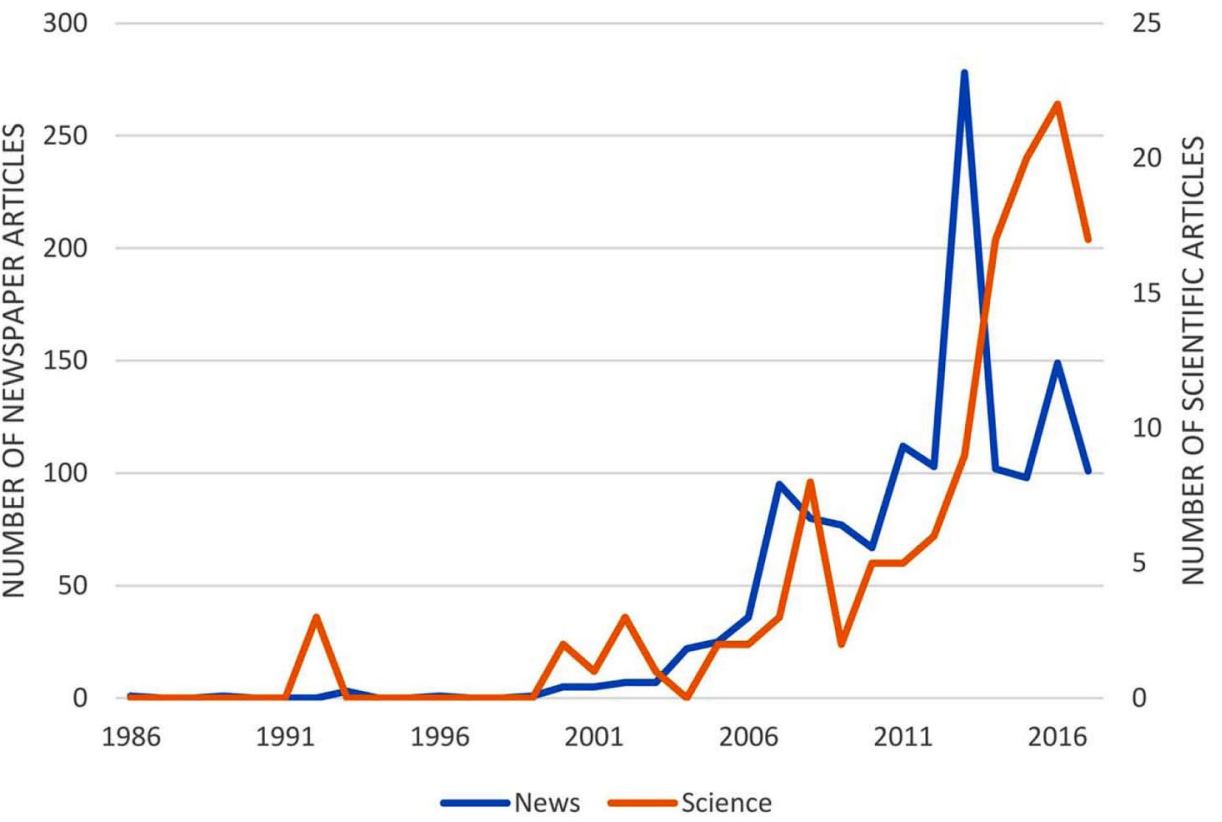

Figure 1. Number of scientific and newspaper articles reporting on pornography addiction.

nature. For newspaper accounts, this often came in the form of journalists, who quoted or referenced "both sides" of the addiction debate, or op-eds that explicitly critiqued a pornography addiction framework. For scientific studies, most articles used language that did not definitively dismiss pornography as addictive but instead argued that existing research is too limited to support pornography as addictive, almost always making comparisons to other well-researched addictions such as cocaine, alcohol, and gambling.

Compared to newspaper articles and state resolutions, scientific articles were the least likely to support an addiction framework, and we found less support among neuro-physiological research than psycho-social studies. Seventy-six percent of psycho-social articles that referenced pornography addiction supported an addiction framework, compared to 55 percent of neuro-physiological articles. Psycho-social articles outnumbered neuro-physiological articles by nearly seven to one and were better positioned to support an addiction framework by using self-reports of perceived addiction or addiction-like behavior. Neurophysiological articles that did not include self-reported measures used criteria to define and measure addiction neuro-physiologically, 


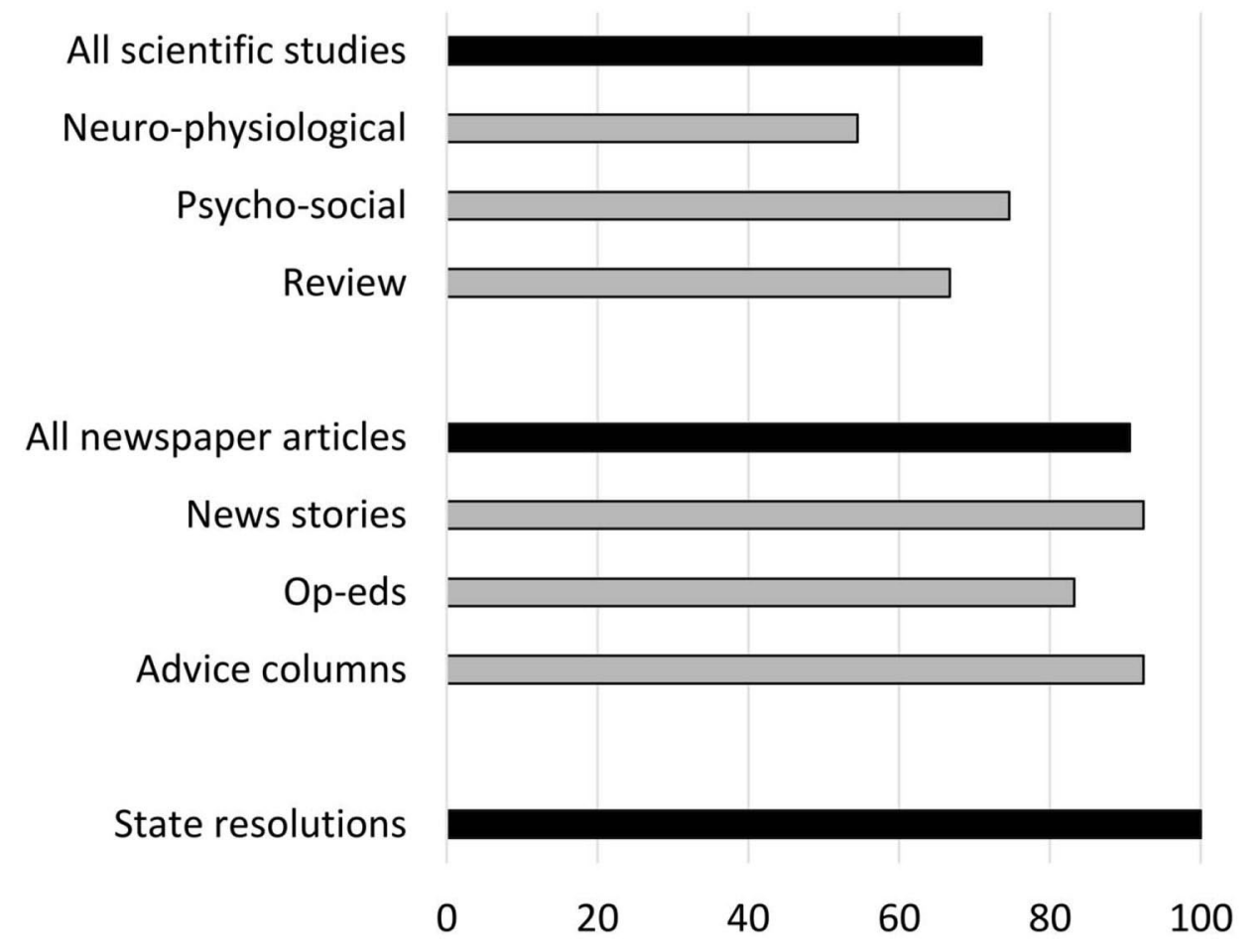

Figure 2. Percentage of scientific studies, newspaper articles, and state resolutions that support a pornography addiction framework.

and these noted common limitations. First, for those using cross-sectional designs, researchers could not determine whether the differences they observed preceded or followed pornography consumption. Second, as an article published in 2015 in Frontiers in Human Neuroscience describes, neurological researchers who work under the assumption that the brain responds to cue and reward differently when studying addiction (i.e., what triggers the addictive behavior and to what effect) test pornography itself as a reward behavior rather than as a cue for future reward. In other words, in the lab, participants are typically instructed that they should not masturbate while being exposed to visual sexual stimuli or pornographic material. These studies may lack construct validity measuring pornography as a reward, whereas in real-life pornography, it is most often a "cue" for some other rewards (i.e., masturbation or partnered sex).

All state resolutions support the addiction framework and make neurophysiological claims about pornography's harms (e.g., references to the brain, biology, or neurological evidence). Most states use broad 
descriptions of scientific conclusions instead of specific references to scientific research. ${ }^{3}$ For instance, state resolutions from Oklahoma and South Carolina include the phrase: "recent neurological research indicates that pornography is potentially biologically addictive." All resolutions reference the brain and that pornography is addictive. All but two resolutions use the phrase "biologically addictive."

In comparison, 36 percent of newspaper articles $(n=175)$ that reference pornography addiction mention specific neuro-physiological evidence. These claims do not necessarily come from scientific experts. Instead, we find that newspaper articles draw from a variety of professionals who are not scientists to comment on pornography addiction. For example, one newspaper article published in The Hartford Courant (Connecticut) quotes two therapists who work with men suffering from compulsive sexual behavior. One explains that "the brain scans of sex addicts exposed to the stimuli such as pornography mirrored the brain scans of cocaine addicts when shown a line of cocaine." As indicated in table 2, there are no neuroscientists among the "speakers" most frequently mentioned in newspaper articles; instead it is a combination of politicians, authors, therapists, leaders of nonprofit organizations, and social science researchers, many of whom were quoted making neuro-physiological claims. The two speakers mentioned in the most articles in our sample, Craig Gross and Michael Leahy, are both self-identified Christians who have founded organizations focused on helping fellow Christians avoid pornography. Both news media and state resolutions draw from sources of authority beyond the scientific community (and specifically the neuroscientific community) to comment on the addictive nature of pornography while still emphasizing the neuro-physiological foundation of pornography addiction.

\section{Constructing Pornography Addiction's Harms}

Most newspaper and scientific articles and state resolutions that mention "pornography addiction" implicitly or explicitly support it and therefore also support the notion that pornography can cause harm. Our findings identified four broad categories of harm, which are listed in table 3. The first of these, harm to the consumer, is the mostly 
Table 2. Names and Positions of Most Frequently Mentioned Speakers in Newspaper Articles

\begin{tabular}{llc} 
Name & Position & Number of articles \\
\hline Craig Gross & Christian activist and author & 52 \\
Michael Leahy & Christian activist and author & 50 \\
Clay Olsen & Activist and nonprofit director & 28 \\
Gary Herbert & Politician & 21 \\
Jill C. Manning & Sex therapist and author & 18 \\
Pamela Atkinson & Activist and nonprofit director & 18 \\
Mary Anne Layden & Professor of psychopathology & 18 \\
Todd Weiler & Politician & 17 \\
Gail Dines & Activist and professor of sociology & 11 \\
Robert Weiss & Sex addiction therapist & 8 \\
\hline
\end{tabular}

closely associated with the medical effects of biological addiction. This harm centers around the individual health consequences that stem from pornography addiction and is deployed relatively evenly across scientific, media, and political sources. The other three harms- harms to man-woman relationships, harms to lawful behavior, and harm to normal sexual desires-illustrate the extent to which pornography addiction is a biomedical phenomenon. These are disproportionately deployed within the contexts of media and politics and expand beyond

Table 3. Categories of Harm and Percentage of Scientific Studies, Newspaper Articles, or State Resolutions Evoking Them

\begin{tabular}{|c|c|c|c|c|}
\hline Harm to... & Examples & $\begin{array}{c}\text { Scientific } \\
\text { studies (\%) }\end{array}$ & $\begin{array}{l}\text { Newspaper } \\
\text { articles (\%) }\end{array}$ & $\begin{array}{c}\text { State } \\
\text { resolutions (\%) }\end{array}$ \\
\hline Consumer & $\begin{array}{l}\text { Low self-esteem; depression } \\
\text { and anxiety; damaged brain } \\
\text { development; sexually } \\
\text { transmitted infections }\end{array}$ & 74 & 94 & 100 \\
\hline $\begin{array}{l}\text { Men's } \\
\text { relationships } \\
\text { with women }\end{array}$ & $\begin{array}{l}\text { Thwarted friendships or } \\
\text { romances; marital conflict; } \\
\text { delayed marriage; extramarital } \\
\text { affairs; objectification or } \\
\text { mistreatment of women }\end{array}$ & 20 & 60 & 100 \\
\hline Lawful behavior & $\begin{array}{l}\text { Violence and aggression; } \\
\text { robbery; sex trafficking; sex } \\
\text { work }\end{array}$ & 1 & 13 & 94 \\
\hline Normal desires & $\begin{array}{l}\text { Shocking, extreme, or deviant } \\
\text { sexual interests including group, } \\
\text { same-sex, hardcore, or kinky sex; } \\
\text { misinformation about real-life sex }\end{array}$ & $x$ & 13 & 94 \\
\hline
\end{tabular}


the physical or emotional consequences of addiction that affect the individual consumer and instead evoke broader ideas about the social good. We categorize these as indirect harms to society. The ways in which scientific studies, newspaper articles, and state resolutions articulate the harms of pornography contribute to its moral and political charge, casting judgment not only on pornography consumption itself as an addictive behavior but also broader ideas related to binary gender and heteronormative forms of sexuality.

\section{Harm to the Consumer}

\section{Who are the consumers?}

Although we found repeated reference across all three datasets to what some sources describe as the "triple A threat" of pornography in the twenty-first century- it is affordable (through free streaming online sites), accessible (through widespread Internet access, including smart phones), and anonymous (through private virtual consumption)-most sources position young men as the most likely group to experience the health-related harms of pornography addiction. Some state resolutions describe those who consume pornography in generic terms, for example, using the phrase "the pornography user." News articles often used gender-neutral language to reflect a neutral journalistic style. Op-eds more frequently used the first or second person ("I" or "we" or "you"), like the one published in The New York Times, which states "we're exposed to pornography" and references "people" who look at porn. Yet, figures 3 and 4 show how our data disproportionately describe men and youth as the users (and potential addicts) of pornography, situating this group (i.e., young men) to be the presumed consumers of porn and most likely to be affected by pornography addiction's harms.

Figure 3 shows that 45 percent of newspaper articles (220 of 489) describe only men as the consumers of pornography, compared to 40.3 percent (196 articles) that do not include gender markers; 13.3 percent (64 articles) that mention both men and women explicitly; and 1.2 percent ( 4 articles) that mention only women. For state resolutions, the same number describes men as the exclusive consumers of pornography as those that do not include gender markers (7 resolutions, or 38.9 percent). Twenty-two percent of state resolutions (4 of 


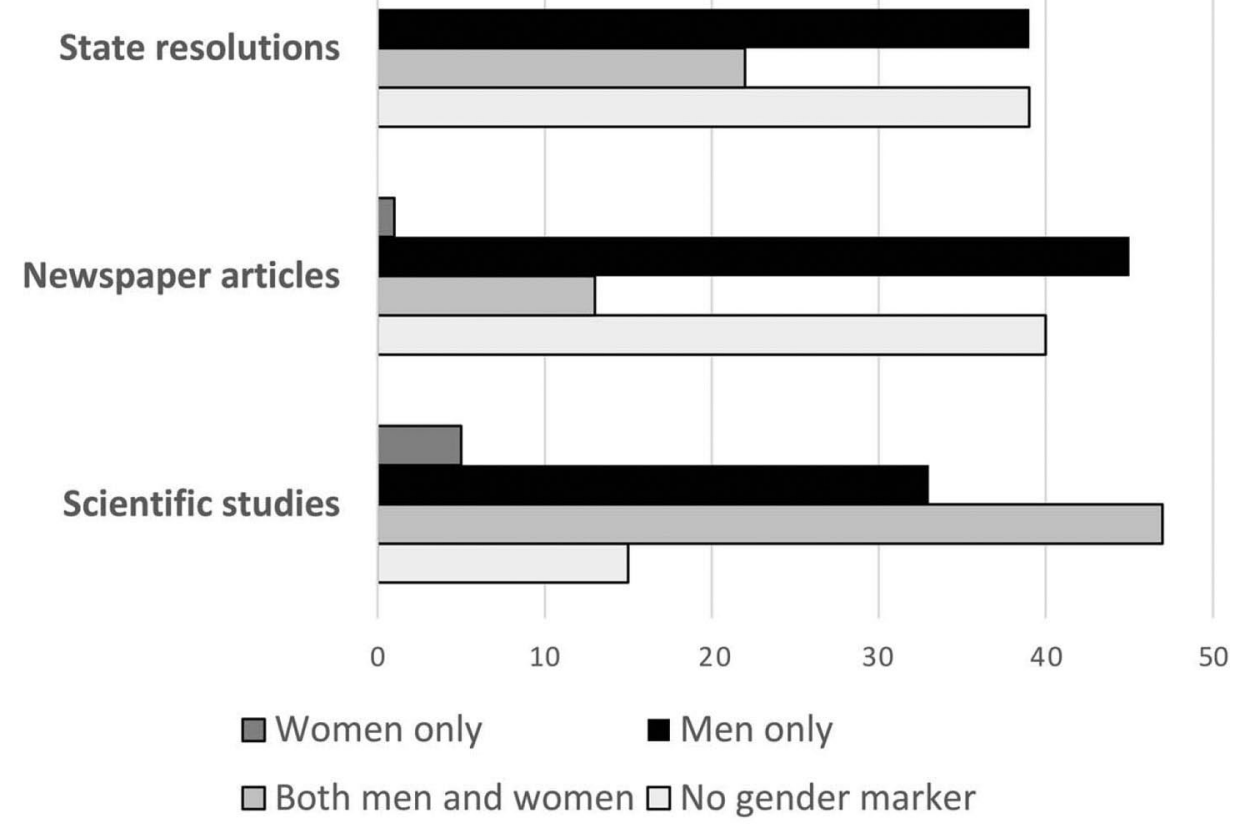

Figure 3. Gender of pornography consumer referenced by percentage of state resolutions, newspaper articles, and scientific studies.

18) describe pornography users as both men and women, and none focus exclusively on women as pornography consumers. Newspaper article titles that illuminate the gender of pornography consumers include "Husband's porn habit frustrates wife" (Spokesman Review, Washington), "Anna Duggar shares pain from Josh Duggar's cheating, porn addiction" (The East Bay Times, California), and "Dear Abby: Despite promise to stop, man resumes watching pornography” (St. Paul

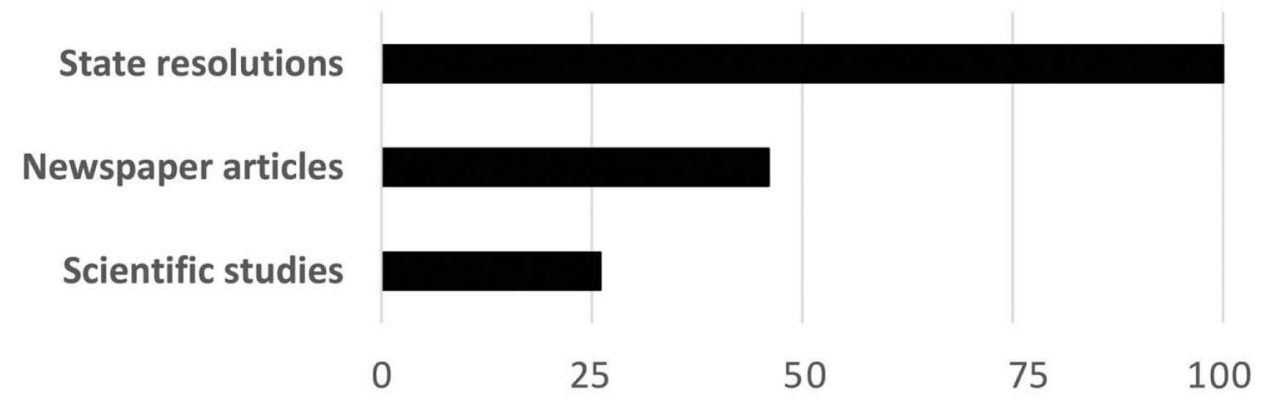

Figure 4. Percentage of state resolutions, newspaper articles, and scientific studies that explicitly reference youth as consumers of pornography. 
Pioneer Press, Minnesota). Though some newspaper articles diverge from this pattern, like one op-ed titled, "Pornography and Sex Addiction: Not Just a Man's Problem” (Deseret News, Utah), most reinforce an assumed relationship between men and pornography addiction.

As shown in figure 4 , both newspaper articles and state resolutions emphasize that young people are most at risk of becoming addicted to pornography. Nearly half of the newspaper articles in our sample (46 percent or 225 articles) explicitly mention this group, which we coded as any reference to "children," "youth," "teens," "adolescents," or "students," as the likely consumers of pornography. Newspaper titles dramatize the risk of pornography to youth: "Ask Amy: Family wrestles with how to cope with teen's addiction" (The Washington Post, Washington, DC), "Pornography's young victims" (Deseret News, Utah), and “Internet feeds kids' porn diet" (Orange County Register, California). In the op-ed quoted in our introduction, Rabbi Shmuley Boteach and former Playboy model Pamela Anderson describe today's generation of children as the "crack babies of porn" (The Wall Street Journal, Washington, DC). Louisiana's state resolution, mentioning the "proliferation of pornography among Louisiana children," offers a unique emphasis on the protection of youth, but all state resolutions describe pornography as leading to "an increase in problematic sexual activity at younger ages" and describe pornography as "contributing to the hyper-sexualization of teens, and even prepubescent children." Over half of the resolutions also include the phrase that pornography "teaches girls that they are to be used and teaches boys to be users" $(n=12)$.

The overall sample of scientific articles tends to include adult samples of men and women (47 percent) and therefore counter trends observed in newspaper and state resolution data. About one in four scientific studies (26.2 percent) referenced young people in the abstract, most often studies that sampled college or university students. Findings from these studies may contribute to the commonly assumed belief in news and politics that young people are particularly likely to become addicted to pornography. Within our sample of neurophysiological studies, 81.8 percent ( 9 of 11) included all-male samples. Though psycho-social studies that analyze gender do find differences in pornography consumption and perceived addiction for men and women, neuro-physiological studies that use all-male samples 
reinforce the assumption that men experience unique physiological harm as a result of pornography consumption. Neurophysiological articles are more similar than psycho-social articles to newspaper articles and state resolutions in the likelihood of exclusively emphasizing men as the consumers of pornography. This serves to reinforce a medicalized model of men's biological predisposition to become addicted to pornography and thus perpetuates the stereotype that men have innate and uncontrollable sexual urges. Women, who may be literally excluded from a neuro-physiological study's sample, are then figuratively understood to lack these same sexual desires.

\section{How are consumer's harmed?}

As table 3 shows, the most frequently cited harm in scientific research, newspaper articles, and state resolutions was what we categorize as health-related harm to consumers. We coded this harm broadly to encompass any and all consequences related to the emotional, physical, spiritual, or social well-being of individuals (we adapted this from the World Health Organization definition of health). The articles in our sample that implicitly or explicitly support an addiction framework often assume a priori pornography's direct harm to consumers since addiction in and of itself is understood as a medicalized consequence to addicted individuals (Netherland 2012). Within our sample, 74 percent of scientific articles, 94 percent of newspaper articles, and 100 percent of state resolutions described harm to health as a consequence of pornography addiction.

Across datasets, many articles in our sample drew directly from language used to describe substance and other behavioral addictions (most often gambling). Some scientific studies, for example, used addiction language of "cravings," "attentional biases," and "preoccupancy" (Addiction; Behavioral Science; Journal of Psychiatric Research; PLOS ONE; Sexual and Reproductive Health). In one article in Behavior Science reviewing neuroscientific research on pornography addiction, the authors describe pornography use like the addictive cycle of drugs: "(1) binge/intoxication; (2) withdrawal/negative affect; and (3) preoccupation/ anticipation." Some newspaper articles quoted activists and politicians who used an analogy to smoking tobacco to describe pornography's harm to physical health. In one article in the Deseret News (Utah), Senator Todd Weiler who authored Utah's state 
resolution says, "Before you pick up a cigarette today, you know that you may be acquiring an addiction. [ ... ] I would like people to know that with porn before they approach it."

In addition to the claims made by a broad range of "experts," newspaper stories often contained personal accounts or anecdotes about the direct harms of pornography addiction. An article in The New York Times profiled Alexander Rhodes, the founder of the popular website NoFap.com, that helps individuals strategize about taking breaks from masturbation and pornography. Rhodes is quoted repeatedly reflecting that he was "addicted to internet porn" and shares the personal consequences of this addiction: he used pornography to cope with emotional problems rather than confronting their source and experienced "porn-induced erectile dysfunction" where he could not maintain an erection unless he watched pornography.

Even for neuro-physiological scientific articles, most negative health consequences were based on self-reports, such as survey or interview data. One PLOS ONE neuro-physiological study measures "neural correlates" of pornography consumption using fMRI and an experimental design but goes on to describe negative outcomes of compulsive pornography consumption based on male participants' self-reports:

[T] hey had lost jobs due to use at work $(N=2)$, damaged intimate relationships or negatively influenced other social activities $(N=16)$, experienced diminished libido or erectile function specifically in physical relationships with women (although not in relationship to the sexually explicit material) $(N=11)$, used escorts excessively $(N=3)$, experienced suicidal ideation $(N=2)$ and using large amounts of money ( $N=3$; from $£ 7$,000 to $£ 15,000$ ). Ten subjects either had or were in counselling for their behaviours.

Other examples of negative emotional consequences presented in scientific studies include psychological distress, narcissism, depression and anxiety, sexual dissatisfaction, loneliness, body image dissatisfaction, and negative self-perception and self-esteem. Surveys or interviews, rather than neurophysiological measures, are typically used to assess these harms to individual consumers of pornography. 
All state resolutions refer to the potential negative health consequences of pornography use, and all but one state (Florida) mention emotional illness. Twelve state resolutions use the phrase that pornography can "contribute to emotional and medical illnesses." Many resolutions refer to specific consequences, such as Georgia's, which describes pornography use "leading to low self-esteem and eating disorders." State resolutions take a clear biomedical approach indicating that pornography addiction is a problem for citizen health and wellbeing and is thus a "public health" concern. As evidence, a total of 13 states include language to suggest that pornography is more than an individual problem. Six states use the phrase, "overcoming pornography's harms is beyond the capability of the afflicted individual to address alone." Framing pornography use in this way removes blame from the individual consumer by situating the risks of pornography as physical and biological rather than a result of poor judgment. The language of resolutions also indicates that their purpose is to raise public awareness as all of the 18 resolutions recognize the need for "education, prevention, research, and policy change."

\section{Harm to Men's Relationships with Women}

Many sources position women as impacted by pornography addiction but as collateral damage rather than direct consumers. Our coding revealed that the relationships targeted as harmed by pornography consumption were specifically man-woman relationships, typically, but not always, that were romantic in nature. These sources perpetuated a binary understanding of gender that assumed heterosexual paring of men with women. Harm to man-woman relationships was the second most common harm described by articles in our sample. Twenty percent of scientific articles $(n=21)$ discuss the correlation between pornography consumption and harm to men's relationships with women, most often focused on quality of marital relationships. According to one Archives of Sexual Behavior study's conclusions, "sexually explicit material enhances perceptions of relationship alternatives which, in turn, increase the likelihood of intimate extradyadic behavior." In other words, viewing pornography increases the likelihood of cheating on a partner. One finding in scientific research is an uneven effect of pornography consumption on men compared 
to women, where negative effects are typically associated with men, while women experience neutral or positive effects on their relationships when they consume pornography. Findings like these are an example of how scientific research is more nuanced and inconclusive when it comes to pornography's harms than are newspaper articles and state resolutions.

Sixty percent of newspaper articles evoked harm to men's relationships with women. Within news media, advice columns consistently supported an addiction frame and most often focused on negative relationship consequences. One reader writes to advice columnists Jann Blackstone-Ford and Sharyl Jupe of The Augusta Chronicle (Georgia) explaining that her marriage ended due to her husband's "infidelity and addiction to porn." The columnist responds by affirming the nature of addictive behavior in relation to pornography: "An addiction to porn and infidelity sometimes go hand in hand. Don't blame yourself. A therapist familiar with porn addiction can help you move on." In another advice column, a reader writes to "Dear Annie" explaining that his wife recently found out about his porn use and claimed it was the same as an extramarital affair. The reader asks Annie if his wife's reaction to his porn use was reasonable. Annie responds that looking at pornography is a betrayal of trust and that cybersex is "a form of cheating." The columnist concludes, "If you cannot stay away from it, consider that you may have an addiction that requires treatment."

All state resolutions imply harms to man-woman relationships, but there is variation. Alabama's resolution does not mention the impact of pornography consumption on marriages or families but does include the claim that pornography "teaches girls to be used and teaches boys to use." Other resolutions (12 of 18 states) make claims that widespread pornography use contributes to the declining marriage rate; most of these (11 of 12) specify that pornography lessens the "desire in young men to marry." Thirteen of eighteen states claim that pornography has "a detrimental effect on the family unit." Emphasizing this harm to the family helps to establish the case that the harms of pornography go beyond the individual and threaten broader social norms. Framing these harms as a threat to the family, and by extension public health, situates pornography use within the purview of the state, facilitating increased regulation of both gender and sexuality. 
In addition to harm to relationships, this category also includes "harm to women," which we coded in vivo along with references to harm to women's bodies or harm to attitudes about women. Though the vast majority of state resolutions evoked harm to women explicitly in addition to harm to men's relationships with women, most newspaper and scientific articles did not reference women outside the context of their relationship with men (articles that discuss harm to women but do not mention addiction to pornography are beyond the scope of our study). Among scientific articles, we coded only three articles that discussed pornography's harm to women outside of relationships to men, two of which offered inconclusive results. Similarly, only 41 of 489 newspaper articles referenced direct harm to women beyond heterosexual relationships. For example, feminist sociologist and antipornography activist, Gail Dines, referenced in 11 articles in our sample, stresses the specific harm to women that pornography causes. One article published in The Heights (Massachusetts) quotes Dines saying that pornography is not "making love" but instead "making hate," referring to hatred toward women. A majority of state resolutions (11 of 18) describe pornography as "treat[ing] women and children as objects and commodities for the viewers' use," presenting women as vulnerable and innocent as children. Additionally, the resolution from West Virginia describes pornography use "by either partner" as "linked to an increased likelihood that girls will engage in group intercourse." Though harm to women dominated feminist debates over pornography in the 1980s (Duggan and Hunter 2006; Whittier 2018), this category of harm was less prominent across news, science, and political outlets in our sample. The rise of pornography addiction, therefore, appears to mark a move away from (though not entire dismissal of) broad feminist-sounding discourse and instead emphasizes biomedical language of women's well-being in the context of interpersonal and romantic relationships with men.

\section{Harm to Lawful Behavior}

Nearly all state resolutions in our sample allude to or explicitly claim that pornography addiction fuels criminal behavior, typically acts of violence or the illegal sex industry, that is, sex work or sex trafficking (see also Bernstein 2018). Harm to lawful behavior was less likely to 
appear in newspaper articles (only 13 percent evoke this harm) and was extremely rare within scientific studies. The single scientific study in our sample that supports the idea that pornography consumption fuels criminal or violent behavior found a positive relationship between pornography use and sexual aggression and victimization (Journal of Sex Research). Like the category "harm to women," many scientific studies and newspaper articles that question the relationship between pornography and violence do not use the phrase "pornography addiction" and therefore fall beyond the scope of our analysis.

Though infrequent, newspaper articles that do evoke this category of harm are likely to detail outrageous and sensational accounts of pornography addiction motivating a crime. An article published in The Bismarck Tribune (North Dakota) features a case of a woman who told investigators that she broke into a neighbor's home multiple times "looking for items she could sell to feed her porn addiction." In another example, a newspaper article published in The Oklahoman (Oklahoma) in 2011 presents the case of a man who confessed to stabbing his wife to death after she confronted him about viewing pornography. The perpetrator told police that he loved his wife but is a "sick individual" who is "addicted to pornography." Though they comprise a very small number in our sample, these articles portray pornography as a serious and transformative addiction, mirroring perhaps dramatic accounts of transformations that take place when unsuspecting "normal” people become addicted to drugs, such as opioids or methamphetamine.

All state resolutions except Texas' mention violence as a consequence of pornography addiction. The Louisiana resolution includes the claim that the age of first exposure to violent pornography correlates with the likelihood of committing acts of violence: "the younger a boy is exposed to images depicting rape, bondage, abuse of women, and other deviant behaviors, the more he is prone to commit violence and force nonconsensual sex with others." Sixteen of eighteen state resolutions mention that pornography "increases the demand for sex trafficking," and all but one resolution describe increased demand for prostitution as a consequence. All but two states mention some unlawful activities associated with child sexual abuse or child pornography. For instance, the Kansas resolution states that pornography "increases child sexual abuse and child pornography and the demand for 
sex trafficking and prostitution." Such resolutions suggest that it is the faceless pornography industry, not men, who should be held responsible for sex trafficking and other forms of exploitation.

\section{Harm to Normal Desires}

The final harm evoked by most state resolutions and some newspaper articles and scientific studies is that pornography addiction harms the development of socially agreed upon standards of "normal" sexual desires. This is reflective of what Rubin (1984) calls the "charmed circle of sexuality," wherein social boundaries between good and bad kinds of sex associate deviant sexual behaviors- like pornographywith other deviant acts. Scientific studies were the least likely type of article to discuss this category. One 2017 example from Sexual and Reproductive Healthcare finds that frequent pornography use was associated with the use of "hardcore" pornography. That the researchers pointed this out suggests that "hardcore" pornography deviates in some significant way from other kinds of pornography (unmarked in this article/i.e., no distinction made with softcore pornography). The only other scientific article to discuss this harm (published in the Journal of Sex Research) finds that men with antisocial personality disorders are more likely to find "extreme or intense" pornography arousing, connecting deviant porn with deviant individuals.

Thirteen percent of newspaper articles also articulated this harm. In one "Dear Abby" column, the writer asks Abby to weigh in on her boyfriend's "Internet porn addiction." The columnist responds, "You should urge Kyle to get help for his addiction. [ . . . ] Although you don't want to lose him, becoming more involved could lead to his wanting to try out his sexual fantasies with you. If you go along with it, it will land you in a world of trouble. The smart thing to do is end this relationship now." The writer does not disclose that her boyfriend is interested in any pornography depicting sex with which she would not approve, but the advice columnist generalizes about pornography addiction in the context of relationships noting that it causes sexual fantasies that are "a world of trouble." A newspaper article published in the Star Tribune of Minneapolis (Minnesota) describes the findings from a recent report published by the Witherspoon Institute. The article explains that "Like alcoholics, porn addicts need increasingly 
novel or bizarre sexual images, over time, to reach the same level of arousal." The article's language that pairs "novel" with "bizarre" suggests that in order to find new porn to consume, one will inevitably venture into deviant territory.

Unlike scientific studies and newspaper articles, most state resolutions (14 of 18) include the phrase that pornography use "shapes deviant sexual arousal." Oklahoma and South Carolina include this claim: "recent neurological research indicates that pornography is potentially biologically addictive, which means the user requires more novelty, often in the form of more shocking material, in order to be satisfied." Hawaii's resolution refers to pornography depicting "extreme degradation and violence" that consumers desire as a consequence of their biological addiction. Louisiana's resolution describes how "young boys" may be "exposed to images depicting rape, bondage, abuse of women, and other deviant behaviors." These allusions to "deviant," "shocking," and "extreme" forms of sexual desire that develop from pornography use assume that pornography taints normal, expected, and demure forms of desire. This language also gives the impression that "normal" men would not choose or intentionally seek "deviant" depictions of sex, were it not for their addiction. Political actors define "deviant" sex when attaching it to pornography as a public health threat.

\section{Conclusion}

As an industry that produces images of and ideas about sex, pornography and the debates that surround it have always reflected deeper and broader social and political conflict (Duggan and Hunter 2006; Strub 2010; Whittier 2018; Jones 2020). In contemporary American society, addiction is the dominant frame by which we understand most compulsive behaviors and excessive pleasures, from social media to sugar (Netherland 2012). And as systems of power often rely on biomedicalized discourse to regulate sexual bodies (Epstein 1996; Haraway 1999; Vogler 2019), it is not surprising that addiction has come to explain pornography and its supposed harms. By analyzing pornography addiction discourse in scientific studies, news articles, and state government resolutions, we find that actors in nonscientific arenas deploy 
scientific-sounding claims in order to make judgments about sexual behavior more convincing even if such claims are not well established in the scientific community. Thus, a wide range of social and political actors claim to be scientific truth-tellers of sexuality and gender. Pornography addiction not only serves as a discourse to shape public perception of sexual desires, behaviors, and relationships that are healthy or unhealthy or good or bad but also allows political actors to use this discourse to legislate what is considered healthy or natural sexuality (Epstein and Mamo 2017).We find that the harms attributed to this addiction reify gender as binary and normative assumptions about (hetero)sexuality.

Our findings reveal that references to pornography as addictive emerged in scientific articles, newspapers, and political documents in the twenty-first century and grew most substantially in the last decade. Most of these sources implicitly or explicitly reproduce the pornography addiction framework that they reference, but scientific studies are more likely than newspaper articles or state resolutions to explicitly challenge or critique a pornography addiction framework. Broad cultural understandings of addiction position neuro-physiological studies as the best equipped to validate pornography addiction since addiction is understood as a "brain disease" (Vrecko 2010a; Netherland 2011), yet these studies are the least likely in our sample to make broad conclusions that pornography is addictive in ways that are similar to drugs, alcohol, or gambling. Most newspaper articles that reference pornography addiction take for granted the concept and therefore implicitly support it, yet the articles most often mention public figures who are not neuroscientists of addiction and are instead activists, politicians, religious figures, and therapists. All state resolutions in our sample explicitly support pornography addiction as a concept and rely on biomedical language to construct pornography as a threat not only to individual consumers but also to broader groups and communities. This reliance on biomedical language allows political actors to present a seemingly objective and factual account of the harms of pornography that are more convincing than claims about morality that may seem outdated or out of place in the political sphere (Thomas 2013; Strub 2010).

Our analysis of how arenas of public discourse construct harms associated with pornography addiction illustrates the social and political 
stakes of biomedicalized concepts related to sexuality. Just as sociologists of other addictions argue that the shared understanding of addiction as "biological" is made meaningful only through social situations (Keane 2002; Weinberg 2002), we find that public discourses construct pornography addiction as a social problem by articulating a wide range of harms, including direct harms to consumers and indirect harms to broader society. These discourses do more than pathologize pornography itself but also pathologize individuals and relationships that fall outside of normative definitions of gender and sexuality. Most scientific, newspaper, and government sources support the idea that pornography addiction causes negative health consequences for young men who, according to these sources, are the most likely consumers of pornography. By positioning men as victims of their sexual addictions, these sources perpetuate stereotypes about men's uncontrollable sexual urges and their natural tendency toward sexual aggression and even violence. Inversely, the lack of discussion surrounding women and pornography consumption implies that women do not experience these strong sexual urges and instead serve to temper men's sexuality (see also Irvine 2005 [1990]; Westbrook and Schilt 2014).

Political actors, and to a lesser extent the media, also present pornography as biologically addictive in order to describe a number of indirect harms that impact groups, communities, and broader society beyond male consumers themselves. By focusing on the so-called harms that pornography addiction causes, these sources implicitly protect male consumers and bypass potential blame directed at men. Notably, the idea that pornography harms women is less common in pornography addiction discourse than the idea that pornography harms men's relationships with women. Thus, critiques of patriarchy, which dominated the anti-pornography movement in the 1980s (Duggan and Hunter 2006; Whittier 2018), are less salient in public discussion of pornography addiction. Instead, pornography addiction discourse emphasizes men as the victims of pornography and the subsequent problems of strained heterosexual relationships, sex trafficking and other forms of criminal activities, and "deviant" sexual interests. Scientific studies are the least likely sources to support the relationship between pornography addiction and all of these harms, suggesting that journalists and political actors are overextending scientific findings to 
advance their media markets and political agendas. These sources use the meaning of pornography addiction to codify gender stereotypes and normative heterosexuality and to reinforce a particular sense of the social good.

\section{About the Authors}

Kelsy Burke is an Assistant Professor of Sociology at the University of Nebraska- Lincoln where she researches sexuality, culture, and religion in the contemporary United States. Her first book is Christians under Covers: Evangelicals and Sexual Pleasure on the Internet (2016, University of California Press).

Alice MillerMacPhee is a doctoral candidate in Sociology at the University of Nebraska-Lincoln. Her research focuses on organizations and policy development, and her dissertation examines the role of organizations in immigration advocacy and policy reform in the Midwest.

\section{Notes}

1. For all of our data sources (PubMed, LexisNexis, and state government resolutions), we excluded articles on child pornography because news, science, and political documents describe consumers of this type of pornography in distinctly pathological ways that qualitatively differ from other discussions of pornography consumption.

2. The National Center for Sexual Exploitation (NCOSE) is a 501(c)(3) nonprofit organization describing itself as a "leading national organization exposing the links between all forms of sexual exploitation such as child sexual abuse, prostitution, sex trafficking and the public health crisis of pornography." All state resolutions include language similar to NCOSE's "model resolution" (https://endsexualexploitation.org/wp-content/uploads/ Pornography-Public-Health-Crisis-Resolution_Draft-Feb-2016.pdf) from February 2016 but none explicitly reference NCOSE in the text of the resolution. This model mentions Utah, which is the first state to adopt a resolution using this language. We do not know if authors of remaining resolutions base them on the Utah resolution, the NCOSE model, or both.

3. Although resolutions do not cite specific scientific research, the model resolution created by the National Center for Sexual Exploitation (see Note 2) cites scientific journal articles (most that are psycho-social rather than neuro-physiological) and a survey conducted by an evangelical-affiliated research firm, the Barna Group. Additionally, legislative floor debates may have included research citations but those fall beyond the scope of this study. 
Acknowledgments This research was partially supported by the University of $\mathrm{Ne}$ braska-Lincoln Behavioral Health Program of Excellence; the University of NebraskaLincoln Department of Sociology Ogle Summer Graduate Fellowship; the University of Nebraska-Lincoln Department of Sociology Undergraduate Sociological Teaching and Research (USTAR) program; and the University of Nebraska-Lincoln Undergraduate Creative Activities and Research Experience (UCARE) program. We thank Eliza Thor, Claire Bartels, Jordan Malzer, Erika Llano, and Nicholas Martinez for their research assistance. We are grateful for comments from readers of early versions of the paper, including Christina Falci, Amy McDowell, Philip Schwadel, and the Culture, Power, and Inequality workshop group at the University of Colorado Boulder Department of Sociology.

\section{References}

Attwood, Feona (ed.) 2010. Porn.com: Making Sense of Online Pornography. New York: Peter Lang.

Balasubramanian, Savina. 2018. "Motivating Men: Social Science and the Regulation of Men's Reproduction in Postwar India." Gender \& Society 32 (1): 34-58.

Barker, Kristen, and Tasha R. Galardi. 2015. "Diagnostic Domain Defense: Autism Spectrum Disorder and the DSM-5." Social Problems 62 (1): 120-40.

Benford, Robert D., and David A. Snow. 200o. "Framing Processes and Social Movements: An Overview and Assessment." Annual Review of Sociology 26 (1): 611-39.

Bernstein, Elizabeth. 2018. Brokered Subjects: Sex, Trafficking, and the Politics of Freedom. Chicago: University of Chicago Press.

Brint, Steven. 1996. In an Age of Experts: The Changing Role of Professionals in Politics and Public Life. Princeton University Press.

Burke, Kelsy and Trenton Haltom. 2020. "Created by God and Wired to Porn: Redemptive Masculinity and Gender Beliefs in Narratives of Religious Men's Pornography Addiction Recovery." Gender and Society 34 (2): 233-258.

Callahan, Daniel. 2012. The Roots of Bioethics: Health, Progress, Technology, Death. New York: Oxford University Press.

Clarke, Adele E., Janet K. Shim, Laura Mamo, Jennifer Ruth Fosket, and Jennifer R. Fishman. 2003. "Biomedicalization: Technoscientific Transformations of Health, Illness, and U.S. Biomedicine." American Sociological Review 68 (2): 161-94.

Clarkson, Jay, and Shana Kopaczewski. 2013. "Pornography Addiction and the Medicalization of Free Speech.” Journal of Communication Inquiry 37 (2): 128-48.

Davis, Georgiann. 2015. Contesting Intersex: The Dubious Diagnosis. New York: New York University Press. 
Duggan, Lisa and Nan D. Hunter 2006. Sex Wars: Sexual Dissent and Political Culture. New York: Taylor \& Francis.

Epstein, Steven. 1996. Impure Science: AIDS, Activism, and the Politics of Knowledge. Berkeley: University of California Press.

Epstein, Steven and Laura Mamo. 2017. "The Proliferation of Sexual Health: Diverse Social Problems and the Legitimation of Sexuality." Social Science \& Medicine 188:176-90.

Evans, John H. 2018. Morals Not Knowledge: Recasting the Contemporary U.S. Conflict Between Religion and Science. Berkeley University of California Press.

Ferree, Myra Marx, William Anthony Gamson, Jügen Gerhards and Deiter Rucht. 2002. Shaping Abortion Discourse: Democracy and the Public Sphere in Germany and the United States. New York: Cambridge University Press.

Foucault, Michel. 1990 [1978]. An Introduction. Vol. 1, The History of Sexuality. Translated by Robert Hurley. New York: Vintage.

Frickel, Scott and Kelly Moore (eds.). 2006. The New Political Sociology of Science: Institutions, Networks, and Power. Madison: University of Wisconsin Press.

Gauchat, Gordon. 2015. "The Political Context of Science in the United States: Public Acceptance of Evidence-Based Policy and Science Funding." Social Forces 94 (2): 723-46.

Hallin, Daniel C., Marisa Brandt and Charles L. Briggs. 2013. "Biomedicalization and the Public Sphere: Newspaper Coverage of Health and Medicine, 1960s-200os." Social Science \& Medicine 96:121-8.

Haraway, Donna. 1999. "The Biopolitics of Postmodern Bodies: Determinations of Self in Immune System Discourse". In Feminist Theory and the Body: A Reader, edited by Price, Janet, Shildrick, Margrit, pp. 203-14. New York: Routledge.

Hoppe, Trevor. 2018. Punishing Disease: HIV and the Criminalization of Sickness. Berkeley: University of California Press.

Irvine, Janice M. 2005 [1990]. Disorders of Desire: Sex and Gender in Modern American Sexology. Philadelphia: Temple University Press.

Jones, Angela. 2020. Camming: Money, Power, and Pleasure in the Sex Work Industry. New York: New York University Press.

Keane, Helen. 2002. What's Wrong with Addiction? New York: New York University Press. Cetina, Knorr Karin. 1999. Epistemic Cultures: How the Sciences Make Knowledge. Cambridge: Harvard University Press.

Kor, Ariel, Yehuda A. Fogel, Rory C. Reid, and Marc N. Potenza. 2013. "Should Hypersexual Disorder be Classified as an Addiction?” Sexual Addiction \& Compulsivity, 20 (1-2): 27-47.

Laqueur, Thomas W. 2003. Solitary Sex: A Cultural History of Masturbation. Brooklyn, NY: Zone Books.

Loe, Meika. 2001. "Fixing Broken Masculinity: Viagra and the Production of Gender and Sexuality." Sexuality and Culture 5 (3): 97-125.

Moore, Kelly. 2013. Disrupting Science: Social Movements, American Scientists, and the Politics of the Military, 1945-1975. Princeton University Press. 
Moser, Charles. 2013. "Hypersexual Disorder: Searching for Clarity." Sexual Addiction \& Compulsivity 20 (1-2): 48-58.

Netherland, Julie. 2011. "We haven't Sliced Open anyone's Brain yet': Neuroscience, Embodiment and the Governance of Addiction”. In Sociological Reflections on the Neurosciences, edited by Pickersgill, M., Keulen, I.V., pp. 153-7. Bingley, UK: Emerald Group Publishing Limited.

- 2012. "Introduction: Sociology and the Shifting Landscape of Addiction". In Critical Perspectives on Addiction, edited by Netherland, J., pp. 11-25. Bingley, UK: Emerald Group Publishing Limited.

Neuendorf, Kimberly A. 2002. The Content Analysis Guidebook. Thousand Oaks: Sage.

Oeming, Madita. 2018. "A New Diagnosis for Old Fears? Pathologizing Porn in Contemporary US Discourse.” Porn Studies 5 (2): 213-16.

Paasonen, Susanna. 2011. Carnal Resonance: Affect and Online Pornography. Cambridge: MIT Press.

Perry, Samuel. 2019. Addicted to Lust: Pornography in the Lives of Conservative Protestants. New York: Oxford University Press.

Petry, Nancy M., Kristyn Zajac, and Meredith K. Ginley. 2018. "Behavioral Addictions as Mental Disorders: To Be or Not to Be?" Annual Review of Clinical Psychology 14 (1): 399-423.

Potts, Annie, Victoria Grace, Nicola Gavey, and Tina Vares. 2004. "“Viagra Stories”: Challenging 'Erectile Dysfunction'.” Social Science \& Medicine 59 (3): 489-99.

Reay, Barry, Nina Attwood and Claire Gooder. 2015. Sex Addiction: A Critical History. Hoboken: John Wiley \& Sons.

Reich, Jennifer A. 2018. Calling the Shots: Why Parents Reject Vaccines. New York: New York University Press.

Reith, Gerda. 2004. "Consumption and its Discontents: Addiction, Identity, and the Problems of Freedom." The British Journal of Sociology 55 (2): 283-300.

Riska, Elianne. 2010. "Gender and Medicalization and Biomedicalization Theories". In Biomedicalization: Technoscience, Health, and Illness in the U.S., edited by Clarke, Adele E., Mamo, Laura, Fosket, Jennifer Ruth, Fishman, Jennifer R., Shim, Janet K., pp. 147-71. Durham: Duke University Press.

Rose, Nikolas. 2007. The Politics of Life Itself: Biomedicine, Power and Subjectivity in the Twenty-First Century. Princeton: Princeton University Press.

Rubin, Gayle. 1984. "Thinking Sex: Notes for a Radical Theory of the Politics of Sexuality". In Pleasure and Danger: Exploring Female Sexuality, edited by Vance, Carole S., pp. 267-319. New York: Routledge.

Saguy, Abigail. 2013. What's Wrong with Fat? New York: Oxford University Press. Scott, Joan Wallach. 2019. Knowledge, Power, and Academic Freedom. New York: Columbia University Press.

Stone, Amy. 2019. "Frame Variation in Child Protectionist Claims: Constructions of Gay Men and Transgender Women as Strangers." Social Forces 97 (3):

$1155^{-76 .}$ 
Stoops, Jamie. 2017. "Just like Heroin: Science, Pornography, and Heteronormativity in the Virtual Public Sphere." Porn Studies 4 (4): 1-17.

Strauss, Anselm L. 1987. Qualitative Analysis for Social Scientists. New York: Cambridge University Press.

Strub, Whitney. 2010. Perversion for Profit: The Politics of Pornography and the Rise of the New Right. New York: Columbia University Press.

Szasz, Thomas. 1991. "The Medicalization of Sex.” Journal of Humanistic Psychology 31 (3): 34-42.

Thomas, Jeremy N. 2013. "Outsourcing Moral Authority: The Internal Secularization of Evangelicals' Anti- Pornography Narratives." Journal for the Scientific Study of Religion 52 (3): 457-75.

Tiefer, Leonore. 1996. "The Medicalization of Sexuality: Conceptual, Normative, and Professional Issues." Annual Review of Sex Research 7 (1): 252-82.

Travis, Trysh. 2010. The Language of the Heart: A Cultural History of the Recovery Movement From Alcoholics Anonymous to Oprah Winfrey. Chapel Hill: University of North Carolina Press.

Vogler, Stefan. 2019. "Science, Technology, and Sexuality: New Directions in the Study of Sexual Knowledge." Sociology Compass 13 (3): 1-13.

Voros, Florian. 2009. "The Invention of Addiction to Pornography." Sexologies 18 (4): $243-46$.

Vrecko, Scott. 2010a. "Birth of a Brain Disease: Science, the State and Addiction Neuropolitics." History of the Human Sciences 23 (4): 52-67.

- 2010b. "Neuroscience, Power and Culture: An Introduction." History of the Human Sciences 23(1):1-10.

Waidzunas, Tom. 2015. The Straight Line: How the Fringe Science of Ex-Gay Therapy Reoriented Sexuality. Minneapolis: University of Minnesota Press.

Waidzunas, Tom, and Steven Epstein. 2015. "'For Men Arousal Is Orientation': Bodily Truthing, Technosexual Scripts, and the Materialization of Sexualities through the Phallometric Test.” Social Studies of Science 45 (2): 187-213.

Weinberg, Darin. 2002. "On the Embodiment of Addiction." Body \& Society 8 (4): 1-19.

Westbrook, Laurel, and Kristen Schilt. 2014. "Doing Gender, Determining Gender: Transgender People, Gender Panics, and the Maintenance of the Sex/Gender/ Sexuality System." Gender \& Society 28 (1): 32-57.

Whittier, Nancy. 2018. Frenemies: Feminists, Conservatives, and Sexual Violence. New York: Oxford University Press. 